\title{
RANCANG BANGUN SISTEM INFORMASI PEMBAYARAN TPU (TAMAN PEMAKAMAN UMUM) BERBASIS WEB DI SUKU DINAS KEHUTANAN KOTA ADMINISTRASI JAKARTA UTARA
}

\author{
Rinna Rachmatika ${ }^{1}$, dan Syauqi Tamzik ${ }^{2}$ \\ ${ }^{1,2}$ Teknik Informatika, Universitas Pamulang \\ Jl. Surya Kencana No. 1, Pamulang, Tanggerang Selatan-Indonesia \\ E-mail : ${ }^{1}$ dosen00836@unpam.ac.id, ${ }^{2}$ syauqi435@gmail.com
}

\begin{abstract}
ABSTRAK
Kantor Suku Dinas Kehutanan Bidang TPU Kota Administrasi Jakarta Utara saat ini masih memiliki beberapa kekurangan. Beberapa kekurangan tersebut diantaranya adalah media pembayaran IPTM (Izin Penggunaan Tanah Makam), media penyimpanan data warga yang belum terkomputerisasi, serta belum adanya media pendaftaran untuk IPTM (Izin Penggunaan Tanah Makam). Pada penelitian ini penulis menerapkan sistem informasi pembayaran TPU (Taman Pemakaman Umum) untuk mempermudah masyarakat dalam melakukan pendaftaran dan pembayaran di TPU. Sistem informasi adalah kumpulan eleman yang saling berhubungan satu sama lain yang berbentuk satu kesatuan untuk mengintegrasikan data, memproses dan menyimpan serta mendistribusikan informasi. Sistem informasi dapat di definisikan sebagai suatu sistem yang dapat dibuat oleh manusia yang terdiri dari beberapa komponen dalam organisasi untuk mencapai suatu tujuan yang menyajikan informasi. Sistem informasi ini dapat diakses menggunakan computer ataupun smartphone. Pada sistem informasi ini terdapat beberapa menu yang menyediakan banyak informasi antara lain seperti kegiatan-kegiatan yang akan diselenggarakan oleh Suku Dinas Kehutanan Kota Administrasi Jakarta Utara, pendaftaran TPU, penyimpanan data-data TPU di Kota Jakarta Utara dan pembayaran tagaihan TPU Kota Jakarta Utara.
\end{abstract}

Kata Kunci : Pembayaran, Sistem Informasi, Dinas Kehutanan, TPU, IPTM.

\section{PENDAHULUAN}

Sistem Pembayaran sangat dekat dengan kehidupan kita sehari-hari. Hampir setiap saat dalam kegiatan perekonomian sehari-hari terjadi transaksi yang dilakukan para pelaku ekonomi, serta masyarakat umum lainnya. Sadar atau tidak, kegiatan transaksi yang kita lakukan tersebut berkaitan erat dengan sistem pembayaran.

Dinas Pertamanan dan Pemakaman dibentuk sejak diberlakukannya Peraturan Daerah (Perda) Provinsi DKI Jakarta Nomor 10 Tahun 2008 tentang Organisasi Perangkat Daerah. Penggabungan ini didasarkan atas dasar bahwa kedua unit pelaksanan otonomi ini dalam melaksanakan tugas dan fungsinya dikoordinasikan oleh Asisten Pembangunan dan Lingkungan Hidup memiliki tugas dan wewenang untuk membangun dan mengelola taman, jalur hijau, keindahan kota dan makam yang merupakan bagian Ruang Terbuka Hijau Kota [1].

Pada Kantor Suku Dinas Kehutanan Bidang TPU Kota Administrasi Jakarta Utara saat ini masih memiliki kekurangan untuk media pembayaran IPTM (Izin Penggunaan Tanah
Makam), selain itu pihak Suku Dinas Kehutanan Bidang TPU Kota Administrasi Jakarta Utara masih kekurangan juga dalam media penyimpanan data warga yang belum terkomputerisasi, tidak hanya itu saat ini pihak Suku Dinas Kehutanan Bidang TPU Kota Administrasi Jakarta Utara bulum memiliki media pendaftaran untuk IPTM (Izin Penggunaan Tanah Makam).

Oleh sebab itu dari permasalahan di atas penulis membuat "Rancang Bangun Sistem Informasi Pembayaran TPU (Taman Pemakaman Umum) Berbasis Web di Suku Dinas Kehutanan Kota Administrasi Jakarta Utara" yang di dalamnya terdapat info pembayaran IPTM dan konfirmasi pembayaran IPTM yang berada di lingkungan Suku Dinas Kehutanan Kota Administrasi Jakarta Utara sehingga warga dapat melakukan IPTM via bank transfer mengkonfirmasikan pembayaran kepada Admin/Staf di Suku Dinas Kehutanan Kota Administrasi Jakarta Utara melalui aplikasi tersebut dengan mengupload bukti pembayaran serta warga dapat mengetahui status pembayaran Iuran dan mencetak report/hasil pembayaran 
dimanapun warga membutuhkan, selain itu dapat mengoptimalisasikan waktu dalam melakukan pembayaran IPTM.

\section{METODE PENELITIAN}

Penggunaan metode dalam melakukan penelitian, bermanfaat untuk mendukung pembuatan laporan berdasarkan data yang diperoleh selama melakukan penelitian tersebut. Ada beberapa macam metode yang dapat digunakan, diantaranya:

a. Studi Pustaka

Studi ini dilakukan dengan cara mempelajari dan meneliti berbagai literature dari perpustakaan yang bersumber dari: Buku, jurnal ilmiah, dan situs internet.

b. Observasi (Pengamatan)

Teknik pengumpulan data melalui Observasi yang dilakukan dengan mengamati aktifitas kegiatan Kantor Suku Dinas Kehutanan Kota Administrasi Jakarta Utara, khususnya Bidang TPU (Taman Pemakaman Umum).

c. Wawancara

Untuk pengumpulan data melalui teknik wawancara ini penyusun melakukan wawancara kepada Kepala Seksi Pemakaman Suku Dinas Kehutanan Kota Adminisrasi Jakarta Utara dan admin TPU yang terkait pada lokasi setempat.

\section{HASIL DAN PEMBAHASAN \\ A. Implementasi}

Implementasi merupakan tahap lanjutan dari perancangan sistem yang akan dilakukan, termasuk program yang telah dibuat agar siap untuk dioperasikan secara optimal sesuai dengan kebutuhan antara lain adalah dengan menerapkan perancangan antar muka ke dalam bentuk halaman utama, besesrta ruang lingkup aplikasi yang akan digunakan dalam penerapanya nanti.

1. Implementasi Antarmuka

Tahap implementasi sistem dilakukan untuk menguraikan beberapa hal pada sebuah sistem yang telah dibuat sebelum sistem tersebut akan di implementasikan, dengan tujuan menguji sistem apakah sudah layak untuk di implementasikan atau belum. Sedangkan implementasi program merupakan bentuk program yang di jalankan pada sistem yang dikembangkan.

a. Halaman Login Ahli Waris

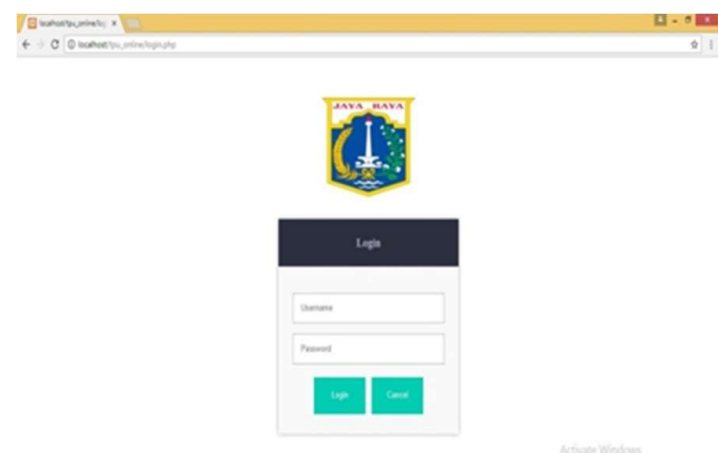

Gambar 3.1 Halaman Login Ahli Waris

b. Halaman Pendaftaran Makam

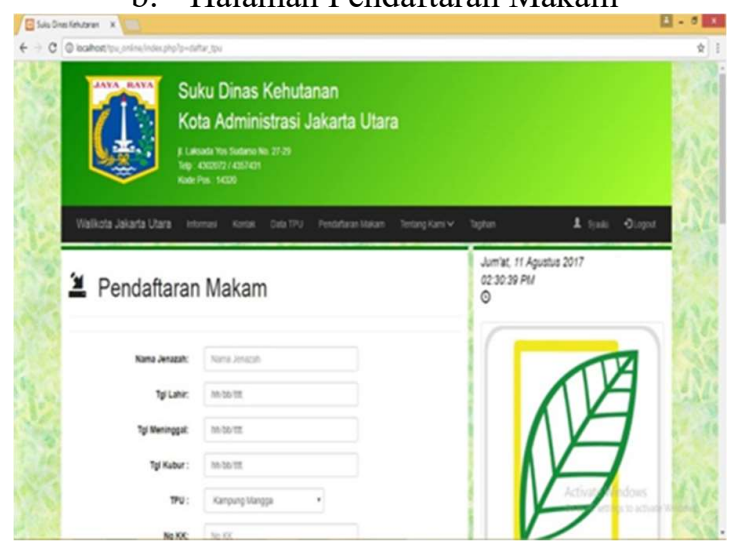

Gambar 3.2 Halaman Pendaftaran Makam

c. Halaman Tagihan Ahli Waris

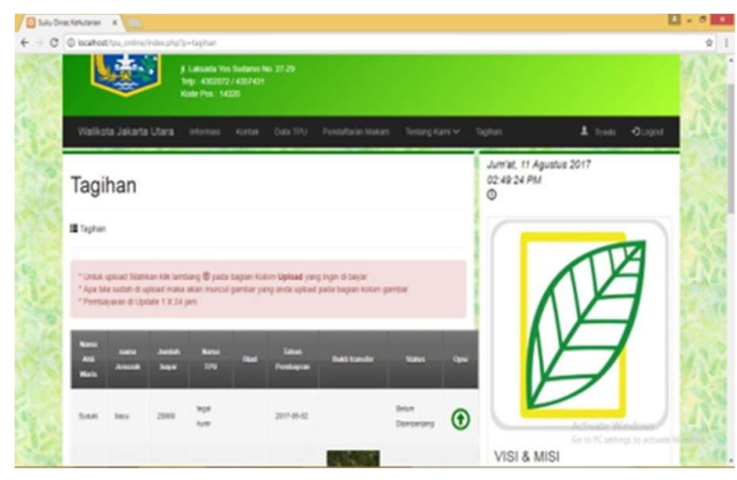

Gambar 3.3 Halaman Tagihan Ahli Waris

2. Pengujian

a. Pengujian White-Box

Pengujian metode white box merupakan metode desain test case yang menggunakan struktur kontrol desain prosedural untuk memperoleh test case. Hal ini dapat menjamin bahwa semua jalur independen pada 
ISSN 2541-1004

suatu modul telah digunakan paling tidak satu kali, menjamin penggunaan semua keputusan logis pada nilai true dan false, menjamin pengaksesan semua perulangan (loop), serta menggunakan struktur data internal untuk menjamin validasinya.

\begin{tabular}{|l|l|l|l|}
\hline No. & $\begin{array}{l}\text { Command } \\
\text { Botton }\end{array}$ & Source Code & Hasil \\
\hline 1. & Login & $\begin{array}{l}\text { Sphp } \\
\text { include 'koneksi.php'; } \\
\text { Susemame =\$_POST['usemame']; } \\
\text { User }\end{array}$ & $\begin{array}{l}\text { Spassword =\$_POST['password']; } \\
\text { if (empty(Susemame))\{ } \\
\text { if } \\
\text { (empty (Susema } \\
\text { me)), tidak } \\
\text { terisi, maka } \\
\text { akan kembalike } \\
\text { halaman login }\end{array}$ \\
\hline
\end{tabular}

Gambar 3.4 Pengujian White-Box

b. Pengujian Black Box

Black Box Testing berfokus pada spesifikasi fungsional dari perangkat lunak. Tester dapat mendefinisikan kumpulan kondisi input dan melakukan pengetesan pada spesifikasi fungsional program. Black Box Testing bukanlah solusi alternatif dari White Box Testing tapi lebih merupakan pelengkap untuk menguji hal-hal yang tidak dicakup oleh White Box Testing [5].

\begin{tabular}{|l|l|l|}
\hline \hline Item Uji & Detail Pengujian & Jenis Pengujian \\
\hline Login & $\begin{array}{l}\text { Verifikasi id } \\
\text { pengguna }\end{array}$ & Black - Box \\
\cline { 2 - 3 } & Verifikasi Password & Black - Box \\
\hline \multirow{4}{*}{$\begin{array}{l}\text { Pengolahan } \\
\text { Informasi }\end{array}$} & Tambah Informasi & Black - Box \\
\cline { 2 - 3 } & $\begin{array}{l}\text { Edit Judul dan } \\
\text { Keterangan } \\
\text { Informasi }\end{array}$ & Black - Box \\
\cline { 2 - 3 } & Batal Informasi & Black - Box \\
\cline { 2 - 3 } & Hapus Informasi & Black - Box \\
\hline
\end{tabular}

Gambar 3.5 Pengujian Black-Box

c. Hasil Pengujian

\begin{tabular}{|l|l|l|l|}
\hline \multicolumn{4}{|c|}{ Data Normal } \\
\hline Data Masukan & $\begin{array}{l}\text { Yang } \\
\text { Di harapkan }\end{array}$ & Pengamatan & Kesimpulan \\
\hline Id Admin & $\begin{array}{l}\text { Tercantum pada } \\
\text { boxisian Id } \\
\text { Admin }\end{array}$ & $\begin{array}{l}\text { Dapat mengisi } \\
\text { login Id Admin. } \\
\text { Sesuai yang } \\
\text { diharapkan }\end{array}$ & Diterima \\
\hline Password & $\begin{array}{l}\text { Tercantum pada } \\
\text { boxisian } \\
\text { password }\end{array}$ & $\begin{array}{l}\text { Dapat mengisi } \\
\text { password.Sesuai } \\
\text { yang diharapkan }\end{array}$ & Diterima \\
\hline Klik Tombol & $\begin{array}{l}\text { Data Id Admin } \\
\text { dan Password } \\
\text { Login }\end{array}$ & $\begin{array}{l}\text { Tombol login } \\
\text { dapat berfungsi. } \\
\text { Sesuai yang }\end{array}$ & Diterima \\
& Login Admin & $\begin{array}{l}\text { Siharapkan } \\
\text { diharina }\end{array}$ & \\
\hline
\end{tabular}

Gambar 3.6 Hasil Pengujian

\section{KESIMPULAN}

Berdasarkan hasil analisa, perancangan dan implementasi maka dapat ditarik kesimpulan sebagai berikut:

1. Dengan adanya sistem informasi ini pihak suku Dinas Kehutanan kota administrasi jakarta utara telah memiliki media pembayaran IPTM yang dapat diakses secara online serta dapat menimalisir keterlambatan pembayaran.

2. Dengan adanya sistem informsi ini pihak suku Dinas Kehutanan kota administrasi jakarta utara telah memiliki media penyimpanan data yang telah terkomputerisasi dan dapat meminimalisir terjadinya kehilangan data.

3. Dengan adanya sistem informasi ini pihak suku Dinas Kehutanan kota administrasi jakarta utara telah memiliki media pendaftaran online untuk pemakaman yang dapat diakses dimana saja oleh ahliwaris.

\section{SARAN}

Saran yang dapat diberikan untuk pengembangan sistem informasi ini antara lain :

1. Untuk pengembangan lebih lanjut pada sistem informasi ini, dapat dikembangkan dengan menambahkan media pembayaran IPTM menggunakan metode M-Banking.

2. Untuk pengembangan lebih lanjut sistem informasi ini, dapat dikembangkan dengan menggunakan framework selain bootstrap seperti; Laravel, CI (Code Igniter), dan Ajax.

3. Untuk pengembangan lebih lanjut sistem informasi ini, dapat dikembangkan dengan menerapkan sistem informasi berbasis android. 


\section{DAFTAR PUSTAKA}

[1] Dinas pertamanan dan pemakaman. (2013). Retrieved from dinas pertamanan dan pemakaman: http://pertamananpemakaman.jakarta.go.id/v40/pr ofil/1/tentang-kami.

[2] Handayani r. (2005). Analisis faktor-faktor yang mempengaruhi minat pemanfaatan sistem informasi dan penggunaan sistem informasi. 12.

[3] Jr, r. M., \& schell, g. P. (2008). Sistem informasi manajemen. Jakarta: salemba empat.

[4] Larasti, m. (2017). Kebijakan pemerintah dalam pemungutan retrebusi .

[5] Mustaqbal, m. S., firdaus, r. F., \& rahmadi, h. (2015, agustus). Pengujian aplikasi menggunakan black box testing boundary value analysis , 4 .

[6] Ulfa, t., \& hidayatullah, m. F. (2015). Sistem informasi pada kantor perpustakaan dan arsip daerah (kanperpus arsipda) kabupaten pekalongan berbasis web. Vol. 1, no. 1, 21. 